\title{
Rhodobium pfennigii sp. nov., a phototrophic purple non-sulfur bacterium with unusual bacteriochlorophyll a antennae, isolated from a brackish microbial mat on Rangiroa atoll, French Polynesia
}

Correspondence

Pierre Caumette

pierre.caumette@univ-pau.fr

\author{
Pierre Caumette, ${ }^{1}$ Rémy Guyoneaud, ${ }^{1}$ Robert Duran, ${ }^{1}$ \\ Cristiana Cravo-Laureau ${ }^{1}$ and Robert Matheron ${ }^{2}$ \\ ${ }^{1}$ Laboratoire d'Ecologie Moléculaire-Microbiologie, EA3525, Université de Pau et des Pays de \\ l'Adour, BP 1155, F-64013 Pau Cedex, France \\ 2Laboratoire d'Ecologie Microbienne IMEP UMR 6116, Université Paul Cézanne, Faculté des \\ Sciences et Techniques de Saint-Jérôme, F-13297 Marseille Cedex 20, France
}

For many years, the remarkable microbial mats found on Polynesian atolls in the central Pacific have been investigated in biogeochemical and microbiological analyses (Mao Che et al., 2001; Guyoneaud et al., 2002). These mats develop in shallow ponds encountered in the large motus (emerged parts) of several atolls in the Tuamotu archipelago of French Polynesia. These mats, locally called kopara, are very impressive in both their beautiful colours and their thickness, with depths of about $20-50 \mathrm{~cm}$. They cover the entire sediment surface of the ponds above the coral reef. These mats consist of stratified layers of filamentous

Abbreviations: BChl, bacteriochlorophyll; LHC, light-harvesting complex. The GenBank/EMBL/DDBJ accession number for the 16S rRNA gene sequence of strain AR2 $102^{\top}$ is AJ510235. cyanobacteria, mainly Phormidium, Schizothrix and Scytonema, that give the mats a gel-like structure. The cyanobacteria are active in the topmost dark-green layer, $2-3 \mathrm{~mm}$ in thickness, according to $\mathrm{O}_{2}$ production (Mao Che et al., 2001). Below, different bacterial groups are distributed along oxygen, sulfide and light gradients. Among these, purple and green anoxygenic phototrophic bacteria have been detected and isolated in large numbers in thin purple or brown layers just below the green cyanobacterial layer (Mao Che et al., 2001). Among these isolates, strain AR2 $102^{\mathrm{T}}$ was investigated, the only strain of purple nonsulfur bacteria that showed unusual light absorption above $900 \mathrm{~nm}$.

Strain AR2 $102^{\mathrm{T}}$ was isolated from a red layer in the first $2 \mathrm{~cm}$ of a microbial mat that had developed in a brackish 
water pond (Pavete; station R2 of Mao Che et al., 2001) on the rim of Rangiroa atoll. The salinity of the water ranged from 5 to 38 p.p.t. depending on the climatic conditions. At the time of sampling, the salinity was 7 p.p.t. and the temperature of the water above the mat was $34^{\circ} \mathrm{C}$. The oxic layer of the mat was $5 \mathrm{~mm}$ in depth; below this depth, the mat was anoxic, containing free sulfide ranging from 0.1 to $2.5 \mathrm{mM}$ in the vertical gradient of the mat (Mao Che et al., 2001).

The strain was isolated from deep-agar dilution series prepared from the red layer. The medium, prepared according to Pfennig \& Trüper (1992), contained the following (per litre distilled water): $\mathrm{KH}_{2} \mathrm{PO}_{4}, 0.35 \mathrm{~g} ; \mathrm{CaCl}_{2} .2 \mathrm{H}_{2} \mathrm{O}$, $0.05 \mathrm{~g} ; \mathrm{NH}_{4} \mathrm{Cl}, 0.5 \mathrm{~g} ; \mathrm{NaCl}, 10 \mathrm{~g} ; \mathrm{MgCl}_{2} .6 \mathrm{H}_{2} \mathrm{O}, 0.7 \mathrm{~g}$; $\mathrm{MgSO}_{4} .7 \mathrm{H}_{2} \mathrm{O}, 0.35 \mathrm{~g} ; \mathrm{NaHCO}_{3}, 1.5 \mathrm{~g}$; vitamin solution V7 (Pfennig et al., 1981), $1 \mathrm{ml}$; trace element solution SL12B (Overmann et al., 1992), $1 \mathrm{ml}$; yeast extract, $0.5 \mathrm{~g}$; disodium succinate, $1.35 \mathrm{~g}(5 \mathrm{mM})$; sodium acetate, $0.68 \mathrm{~g}(5 \mathrm{mM})$. The $\mathrm{pH}$ was adjusted to 6.8. For enrichments and to obtain better growth of pure cultures, the growth medium was supplemented with sodium ascorbate $\left(0.5 \mathrm{~g} \mathrm{l}^{-1}\right)$ in order to maintain reducing conditions.

The cultures were incubated at $30^{\circ} \mathrm{C}$ with light intensity of $50 \mu \mathrm{mol}$ quanta $\mathrm{m}^{-2} \mathrm{~s}^{-1}$ measured within the photosynthetically active radiation ( $16 \mathrm{~h}$ light, $8 \mathrm{~h}$ dark). Purity of cultures was checked by both microscopic observations and growth tests in oxygen gradients established in deep-agar AC medium (Difco), supplemented with thiosulfate $(5 \mathrm{mM})$ and incubated in the dark. Pure cultures in liquid medium were stored in $60 \mathrm{ml} \mathrm{screw}$-capped bottles at $4{ }^{\circ} \mathrm{C}$ in the dark.

Microscopic observations and photomicrographs were made with an Olympus BH-2 photomicroscope according to the method of Pfennig \& Wagener (1986). Flagella were observed by transmission electron microscopy after negative staining with $1 \%(\mathrm{w} / \mathrm{v})$ tungstic acid neutralized to $\mathrm{pH} 7.2$ (JEOL 1200 EX electron microscope). The fine structure of the cells was studied by transmission electron microscopy after fixation of a cell pellet with osmium tetroxide and ultrathin sectioning of the cells according to Reynolds (1963).

Under phase-contrast microscopy, individual cells of strain AR2 $102^{\mathrm{T}}$ were short rods, $0.6 \mu \mathrm{m}$ wide and $1-2 \mu \mathrm{m}$ long, dividing by budding (Fig. 1a). The cells were motile by polar flagella, as revealed by electron microscopy with negative staining (not shown). Small individual cells were actively motile even after successive transfers in synthetic medium, whereas the large cells with buds were less motile or nonmotile. Electron microscopy of thin sections revealed the presence of an intracellular system comprising stacks of lamellar membranes (Fig. 1b).

Absorption spectra of living cells were measured with a Perkin Elmer Lambda 12 spectrophotometer after suspension of a cell pellet in sucrose solution (Pfennig \& Trüper,

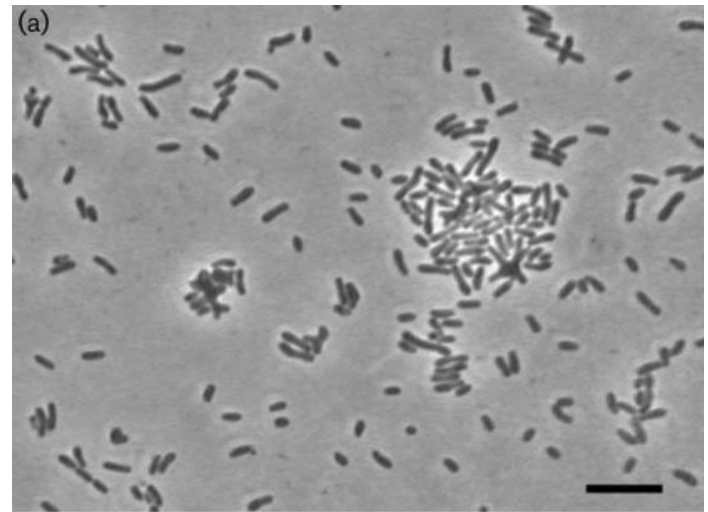

(b)

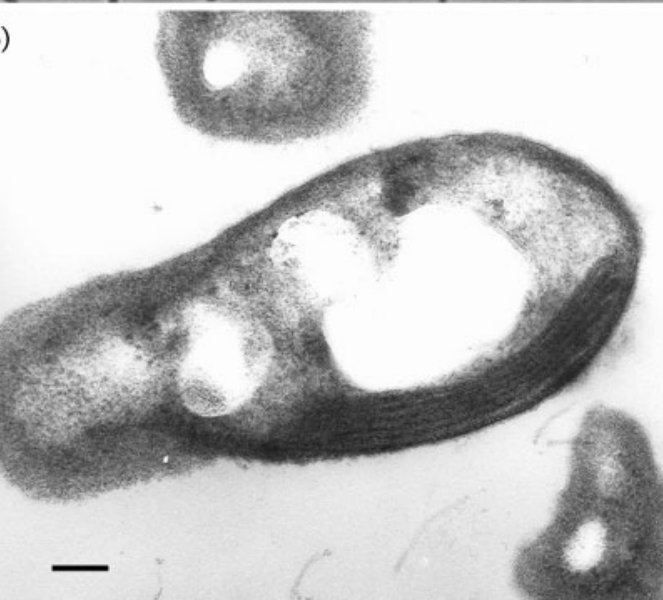

Fig. 1. Phase-contrast photomicrograph (a) and electron transmission photomicrograph of an ultrathin section (b) of cells of strain AR2102 ${ }^{\top}$. Bars, $5 \mu \mathrm{m}$ (a) and $0.1 \mu \mathrm{m}(\mathrm{b})$.

1992). Bacteriochlorophyll (BChl) was identified by its long-wavelength absorption band with the same spectrophotometer, after extraction of the pigments from cell pellets in acetone/methanol $(7: 2, \mathrm{v} / \mathrm{v})$ in the dark and under $\mathrm{N}_{2}$ flow for anaerobic conditions. Carotenoids were determined by HPLC analysis employing a Chromasil C18 separation column and acetonitrile/methanol/dichloromethane $\left(70: 15: 15\right.$, by vol.) as the eluent at $1 \mathrm{ml} \mathrm{min}^{-1}$. The percentage of each carotenoid was calculated from peak areas determined according to Buffan-Dubau et al. (1996).

The colour of the cell suspension of strain AR2 $102^{\mathrm{T}}$ was pink. The absorption spectrum of living cells (Fig. 2) showed typical peaks of BChl $a$, at 378, 594 and $802 \mathrm{~nm}$, and an unusual high peak at $909 \mathrm{~nm}$. The peaks of carotenoids at 483, 512 and $548 \mathrm{~nm}$, with the highest peak at $512 \mathrm{~nm}$, are typical of carotenoids of the normal spirilloxanthin series. The pigment composition determined by HPLC confirmed this biosynthetic pathway, with spirilloxanthin $(95.2 \%)$ as the major carotenoid and small amounts of rhodovibrin and rhodopin (3.1 and $1.7 \%$, respectively).

This pigment composition, with an unusual long-wavelength absorption peak of BChl $a$ at $909 \mathrm{~nm}$, is one of the 


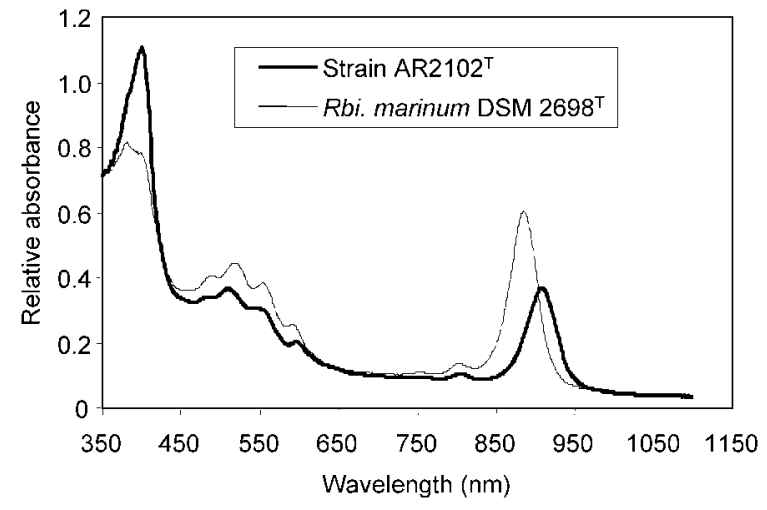

Fig. 2. In vivo absorption spectra of strain $A R 2102^{\top}$ (solid line) and Rbi. marinum DSM $2698^{\top}$ (dotted line).

most interesting characteristics of strain AR2102 ${ }^{\mathrm{T}}$. Several other phototrophic purple bacteria with unusual absorption peaks of BChl $a$ between 911 and $920 \mathrm{~nm}$, e.g. Roseospira thiosulfatophila (Guyoneaud et al., 2002), Roseospirillum parvum (Glaeser \& Overmann, 1999) and Thermochromatium tepidum (Garcia et al., 1986), have been isolated previously. Generally, phototrophic bacteria containing BChl $a$ have three major absorption bands in the near infrared region, at $800,850-860$ and $880-890 \mathrm{~nm}$; the two first bands ( 800 and $850-860 \mathrm{~nm}$ ) correspond to lightharvesting complex (LHC) II and the third $(880 \mathrm{~nm})$ to the low-energy LHC I. In strain AR $2102^{\mathrm{T}}$, as in the three other species mentioned above, LHC I is different, with absorption peaks in the region $909-920 \mathrm{~nm}$. Moreover, strain AR2 $102^{\mathrm{T}}$, together with Rss. parvum, possesses only LHC I, as demonstrated by an in vivo absorption spectrum with only two peaks, a small peak at $800 \mathrm{~nm}$ and a higher peak at 909-911 nm (LHC I). The absence of LHC II is also a characteristic of Rhodobium marinum (Fig. 2). The other two species mentioned above, Ros. thiosulfatophila and Tch. tepidum, possess both LHC I and LHC II, with three absorption bands in the near infrared region (Garcia et al., 1986; Guyoneaud et al., 2002). Another purple bacterium, containing BChl $b$ (Rhodospira trueperi; Pfennig et al., 1997), was found to absorb long wavelengths at $986 \mathrm{~nm}$ in vivo rather than $1025 \mathrm{~nm}$, which is more typical of BChl $b$. Thus, a significant number of strains, all isolated from microbial mats, have the property of harvesting infrared light at wavelengths between 900 and $1000 \mathrm{~nm}$, corresponding to a window in the light spectrum that is not used by most currently known phototrophic purple bacteria that contain typical BChl $a$ or BChl $b$ antennae. With the exception of Tch. tepidum, which was isolated from a mat in a thermal hot spring in Yellowstone National Park (USA), the other three species (Rsa. trueperi, Rss. parvum, Ros. thiosulfatophila) and strain AR $2102^{\mathrm{T}}$ originated from marine laminated microbial mats. They could be considered as characteristic micro-organisms in these mats, where infrared light penetrates deeper, down to the anoxic purple layers below the cyanobacterial top layers. In these purple layers, such bacteria co-exist with purple bacteria containing typical $\mathrm{BChl} a$ or $b$ antennae by using the intermediate wavelengths between 900 and $1000 \mathrm{~nm}$, thus showing the capacity for growth without competition for light over a rather large part of the near-infrared spectrum, between 800 and $1025 \mathrm{~nm}$.

DNA base composition and DNA-DNA hybridization tests were performed by the Identification Service of the DSMZ (Braunschweig, Germany). The G $+\mathrm{C}$ content of the DNA was determined by HPLC as described by Mesbah et al. (1989), using bacteriophage lambda DNA as the standard. Hybridization tests were performed according to the method of De Ley et al. (1970) as modified by Huß et al. (1983).

Genomic DNA isolation was performed as described by Precigou et al. (2001). The 16S rRNA gene was amplified from genomic DNA using universal primers (Lane, 1991; Weisburg et al., 1991) for the bacterial domain. PCR amplification, 16S rRNA gene sequencing and sequence analysis were performed as described by Guyoneaud et al. (2002). Phylogenetic trees were constructed by using the PHYLIP computer package (Felsenstein, 1993). The confidence level of the phylogenetic tree topology was evaluated by performing 100 bootstrap replications with the programs SEQBOOT and CONSENSE.

The neighbour-joining phylogenetic tree is presented in Fig. 3. Strain $\mathrm{AR} 2102^{\mathrm{T}}$ is included in a cluster with all the Rhodobium strains identified so far and is closely related to Rbi. marinum DSM $2698^{\mathrm{T}}$, with $98.3 \%$ 16S rRNA gene sequence similarity. It is more distant from the type strain of the second species of the genus, Rhodobium orientis JCM $9397^{\mathrm{T}}$, with only $94.3 \%$ similarity. It conforms to the description of the genus Rhodobium (Hiraishi et al., 1995). However, the DNA base composition of strain $\mathrm{AR} 2102^{\mathrm{T}}$ was $67.5 \mathrm{~mol} \% \mathrm{G}+\mathrm{C}$ as determined by HPLC. In comparison, the DNA base composition of Rbi. marinum DSM $2698^{\mathrm{T}}$ was determined as $64.2 \mathrm{~mol} \% \mathrm{G}+\mathrm{C}$ by using the same method at the same time, thus showing that strain $\mathrm{AR} 2102^{\mathrm{T}}$ cannot be a member of the species Rbi. marinum. DNA-DNA hybridization between the most closely related type strain, Rbi. marinum DSM $2698^{\mathrm{T}}$, and strain AR $2102^{\mathrm{T}}$ was very low (10.4-17.2\% DNA-DNA relatedness) and clearly confirmed the difference between the two strains.

The ability to utilize various substrates for growth and the optimal concentration of $\mathrm{NaCl}$, optimal $\mathrm{pH}$, light intensity and sulfide tolerance of strain $\mathrm{AR} 2102^{\mathrm{T}}$ were determined according to Guyoneaud et al. (2002).

Fermentative metabolism was tested under anaerobic conditions in the dark with pyruvate as the sole substrate, without addition of electron acceptors. Denitrification was tested under the same conditions with nitrate as the electron acceptor. Microaerophilic growth, vitamin requirements and utilization of nitrogen (ammonium chloride, $5 \mathrm{mM}$; sodium nitrate, $5 \mathrm{mM}$; organic nitrogen in sodium 


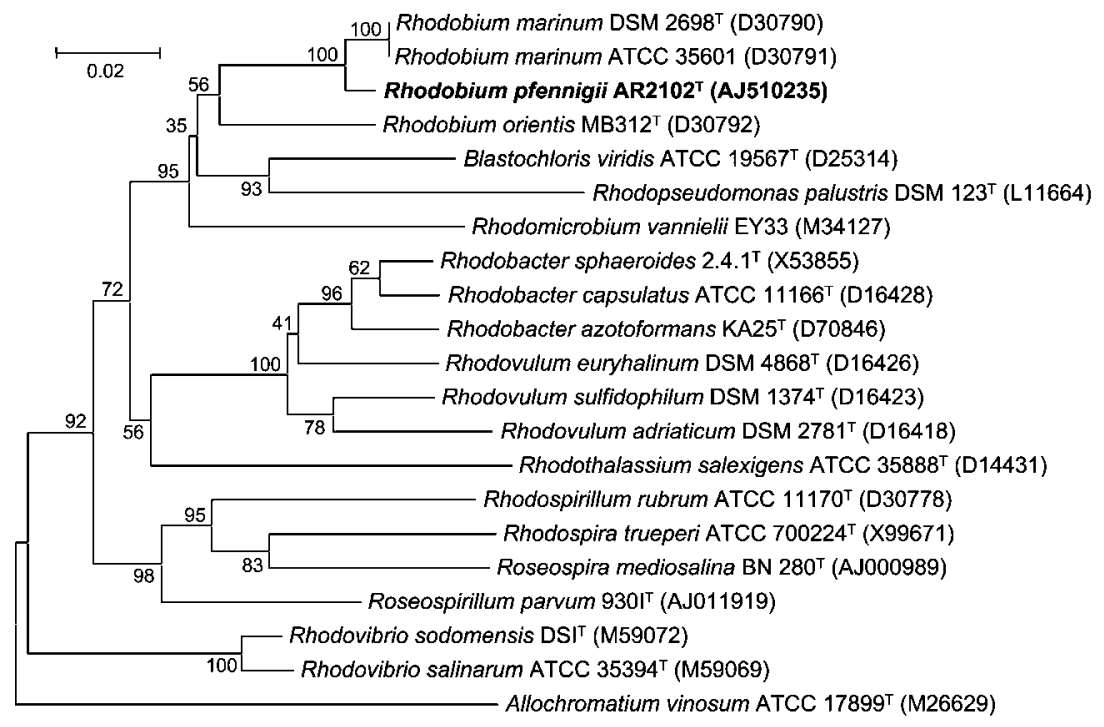

Fig. 3. Dendrogram showing the relationships between the 16S rRNA gene sequences of strain AR2102 ${ }^{\top}$ and related phototrophic purple non-sulfur bacteria (strain numbers and EMBL accession numbers are indicated). The 16S rRNA gene sequence of Allochromatium vinosum ATCC $17899^{\top}$ was included in the sequence analysis to root the tree. Bar, $2 \%$ difference in nucleotide sequence. Numbers on the dendrogram indicate the significance (percentage of outcomes) of the branches (bootstrap analysis).

glutamate, $5 \mathrm{mM}$ ) and sulfur (sulfate, $5 \mathrm{mM}$; sulfide, $2 \mathrm{mM}$; cysteine, $3 \mathrm{mM}$ ) compounds and hydrogen was tested according to Guyoneaud et al. (2002). The presence of catalase was determined by adding a few drops of $3 \%(\mathrm{v} / \mathrm{v})$ $\mathrm{H}_{2} \mathrm{O}_{2}$ to $2 \mathrm{ml}$ of a dense cell suspension.

Strain AR2 $102^{\mathrm{T}}$ grew photo-organotrophically (50$80 \mu \mathrm{mol}$ quanta $\mathrm{m}^{-2} \mathrm{~s}^{-1}$ ) on a wide number of organic substrates, mainly fatty acids and other organic acids (Table 1). The strain grew very well with the following substrates (mM, except where stated): butyrate (4), fumarate (4), succinate (5), pyruvate (5) and 2-oxoglutarate (4). The strain can also use acetate (5), propionate (4), valerate (4), crotonate (2), lactate (5), malate (4), glutamate (4), aspartate (3), cysteine (3), cyclohexanecarboxylate (2), Casamino acids $(0.05 \%)$ and yeast extract $(0.2 \%)$. It was not able to use the following substrates: sulfur, sulfite (2), formate (5), caprylate, pelargonate, palmitate (all at $2 \mathrm{mM}$ ), citrate, methanol, ethanol, propanol, butanol, glycerol, mannitol, glycolate, benzoate, sucrose, trehalose (all at $4 \mathrm{mM}$ ), glucose (5), fructose (5), gluconate, methionine, glycine betaine (all at $3 \mathrm{mM}$ ), thioacetamide, $N$-acetylglucosamine, tartrate, gallate, catechol and nicotinate (all at $2 \mathrm{mM}$ ). Poor photolithotrophic growth was observed only with thiosulfate $(4 \mathrm{mM})$ as electron donor. Strain AR2 $102^{\mathrm{T}}$ was not able to use sulfide ( $2 \mathrm{mM}$ ) but could tolerate sulfide concentrations up to $2-3 \mathrm{mM}$ free sulfide. $\mathrm{H}_{2}$ (2 bars) was not used as an electron donor. Strain AR $2102^{\mathrm{T}}$ utilized a rather similar selection of organic substrates, mainly fatty and organic acids, as the known species of the genus, Rbi. marinum and Rbi. orientis (Table 1 ). However, in contrast to the two known species, strain AR2 $102^{\mathrm{T}}$ was not able to use alcohols or sugars, assimilation of which is an important characteristic of the genus Rhodobium. After three cultures, transferred at the same salinity, the strain could grow without $\mathrm{NaCl}$ in the synthetic medium $\left(\mu=0.003 \mathrm{~h}^{-1}\right)$ and tolerated up to $5 \% \mathrm{NaCl}\left(\mu=0.009 \mathrm{~h}^{-1}\right)$, with optimal growth at $1-2 \%(\mathrm{w} / \mathrm{v}) \mathrm{NaCl}\left(\mu=0.05 \mathrm{~h}^{-1}\right)$. Like the two described Rhodobium species, this new isolate is of marine origin, indicating halotolerant properties. Strain $\mathrm{AR} 2102^{\mathrm{T}}$ is thus well adapted to the brackish environment of the ponds from which it was isolated, the water salinity of which was found to vary between 5 and 38 p.p.t. (Mao Che et al., 2001). It grew well between $\mathrm{pH} 6.3$ and 8.5, with an optimum at $\mathrm{pH}$ 7.2-7.5. The strain showed good growth between 25 and $35^{\circ} \mathrm{C}$.

Growth of strain AR2 $102^{\mathrm{T}}$ was tested at light intensities between 2 and $400 \mu \mathrm{mol}$ quanta $\mathrm{m}^{-2} \mathrm{~s}^{-1}$. Incubated at $30^{\circ} \mathrm{C}$ in the synthetic medium with optimal $\mathrm{pH}$ and salinity, best growth on succinate occurred at $400 \mu \mathrm{mol}$ quanta $\mathrm{m}^{-2} \mathrm{~s}^{-1}$ $\left(\mu=0.100 \mathrm{~h}^{-1}\right.$; doubling time $\left.6.9 \mathrm{~h}\right)$. Growth was still good at $80 \mu \mathrm{mol}$ quanta $\mathrm{m}^{-2} \mathrm{~s}^{-1}\left(\mu=0.08 \mathrm{~h}^{-1}\right)$ and slower at $50 \mu \mathrm{mol}$ quanta $\mathrm{m}^{-2} \mathrm{~s}^{-1}\left(\mu=0.05 \mathrm{~h}^{-1}\right)$. Very slow growth of strain AR2 $102^{\mathrm{T}}$ still occurred at $2 \mu \mathrm{mol}$ quanta $\mathrm{m}^{-2} \mathrm{~s}^{-1}$ $\left(\mu=0.005 \mathrm{~h}^{-1}\right)$. These data show the very wide adaptation to light intensity of strain $\mathrm{AR} 2102^{\mathrm{T}}$.

Chemo-organotrophic growth of strain AR2 $102^{\mathrm{T}}$ with acetate or succinate occurred under microaerophilic conditions in the dark at $2 \mathrm{~mm}$ depth in a tube of agar medium open to air. The strain was also able to grow in shaken liquid cultures under aerobic conditions, showing its capacity to develop in the presence of oxygen in the dark by using a respiratory metabolism. Catalase was present. The strain was unable to grow by fermentative metabolism in the dark, or with nitrate as an electron acceptor. Thiamine or yeast extract were required for growth. Strain AR $2102^{\mathrm{T}}$ was able to grow with sulfate as the sole sulfur source, indicating an assimilatory sulfate reduction pathway. The strain used ammonium chloride or glutamate as a nitrogen source for growth. It could fix dinitrogen but was not able to use nitrate as a nitrogen source.

Thus, according to phylogenetic differences, low relatedness in DNA-DNA hybridization and particularly such strong 
Table 1. Major properties of strain $\mathrm{AR} 2102^{\top}$ in comparison with Rbi. marinum, Rbi. orientis and Rss. parvum

Taxa: 1, strain AR2102 ${ }^{\mathrm{T}}$; 2, Rbi. marinum (data from Imhoff, 1983); 3, Rbi. orientis (Hiraishi et al., 1995); 4, Rss. parvum 930I ${ }^{\mathrm{T}}$ (Glaeser \& Overmann, 1999). +, Utilized; (+), utilized poorly; - , not utilized; +/-, utilized by some strains; ND, no data available. The following substrates were utilized by all four taxa: acetate, butyrate, pyruvate, lactate, malate, fumarate and succinate. Sulfur and sulfite were not used.

\begin{tabular}{|c|c|c|c|c|}
\hline Property & 1 & 2 & 3 & 4 \\
\hline Cell size $(\mu \mathrm{m})$ & $0.6 \times 1-2$ & $0.7-0.9 \times 1-2.5$ & $0.7-0.9 \times 2.5-5$ & $0.4-0.6 \times 1.8-2.6$ \\
\hline Morphology & Rod & Rod & Rod & Vibrioid, spirilloid \\
\hline Flagella & Polar & Polar & Polar & Bipolar \\
\hline Cell division & Budding & Budding & Budding & Binary \\
\hline BChl $a$ absorption peak (nm) & 909 & 883 & 870 & 911 \\
\hline Carotenoids* & $\mathrm{Sp}$ & $\mathrm{Sp}$ & Sp & Sp, la \\
\hline Cytoplasmic membrane & Lamellar & Lamellar & Lamellar & Lamellar stacks \\
\hline DNA G $+\mathrm{C}$ content $(\mathrm{mol} \%)$ & 67.5 & $61.5-64.1$ & $65.2-65.7$ & 71.2 \\
\hline Optimal pH & $7.2-7.5$ & $6.9-7.1$ & $7-7.5$ & 7.9 \\
\hline $\mathrm{pH}$ range & $6.3-8.5$ & ND & ND & ND \\
\hline Optimal salinity (\%) & $1-2$ & $1-5$ & $4-5$ & $1-2$ \\
\hline Salinity range (\%) & $0-5$ & $1-5$ & $2-8$ & $1-6$ \\
\hline Vitamin $(s)$ required $\dagger$ & Thiamine & Complex & p-ABA, biotin & Complex \\
\hline Sulfate assimilation & + & + & + & - \\
\hline \multicolumn{5}{|l|}{ Substrates: } \\
\hline Sulfide & - & + & $(+)$ & + \\
\hline Thiosulfate & $(+)$ & - & + & + \\
\hline Formate & - & + & + & - \\
\hline Propionate & + & + & - & + \\
\hline Citrate & - & $+1-$ & - & - \\
\hline Glucose & - & + & + & - \\
\hline Glycerol & - & $+1-$ & - & - \\
\hline Mannitol & - & + & - & - \\
\hline Ethanol & - & $+1-$ & - & - \\
\hline Gluconate & - & ND & ND & - \\
\hline Hydrogen & - & ND & ND & - \\
\hline
\end{tabular}

${ }^{\star}$ la, Lycopenal; Sp, spirilloxanthin.

$\uparrow p$-ABA, $p$-Aminobenzoic acid

phenotypic differences in pigment composition and the use of substrates from the existing members of the genus, it is justified to consider strain $\mathrm{AR} 2102^{\mathrm{T}}$ as a representative of a novel species, with the name Rhodobium pfennigii sp. nov.

\section{Description of Rhodobium pfennigii sp. nov.}

Rhodobium pfennigii (pfen.ni'gi.i. N.L. gen. n. pfennigii of Pfennig, named after Norbert Pfennig, a German microbiologist).

Straight to ovoid rods, $0.6 \mu \mathrm{m}$ wide and $1-2 \mu \mathrm{m}$ long. Multiplication is by budding. Gram-negative cells are motile by polar flagella. Colour of cell suspension is pink. Stacks of lamellar photosynthetic membranes occur. Contains $\mathrm{BChl} a$ as photosynthetic pigment and spirilloxanthin as the major carotenoid, with small amounts of rhodovibrin and rhodopin. Absorption maxima of living cell suspensions at $395,483,512,548$ and $594 \mathrm{~nm}$ and infrared absorption peak at $909 \mathrm{~nm}$. Electron donors for photo-organotrophic growth are acetate, propionate, butyrate, valerate, crotonate, pyruvate, lactate, malate, fumarate, succinate, 2-oxoglutarate, glutamate, aspartate, yeast extract and Casamino acids. Photolithotrophic growth occurs with thiosulfate; chemoorganotrophic growth occurs under micro-oxic to oxic conditions in the dark with acetate and succinate. Capable of assimilatory sulfate reduction and nitrogen fixation. Thiamine or yeast extract is required for growth. Optimal $\mathrm{pH}$ is 7.2-7.5 (range $\mathrm{pH}$ 6.3-8.5). Optimal temperature is $30-35^{\circ} \mathrm{C}$. Salinity range is $0-5 \%(\mathrm{w} / \mathrm{v}) \mathrm{NaCl}$ (optimum $1-2 \% \mathrm{NaCl}$ ). DNA base composition is $67.5 \mathrm{~mol} \% \mathrm{G}+\mathrm{C}$ (HPLC). Habitat: microbial mats exposed to light in coastal marine environments or brackish ponds.

The type strain is strain AR2102 ${ }^{\mathrm{T}}$ (=ATCC BAA$1145^{\mathrm{T}}=$ DSM $\left.17143^{\mathrm{T}}\right)$, isolated from a benthic microbial mat in a brackish pond (R2) located on the rim of the Rangiroa atoll (French Polynesia). 


\section{Acknowledgements}

This paper is dedicated to Professor Dr Norbert Pfennig. This work has been supported by a grant of the Government of French Polynesia (Ministry of Research) via the KOPARA project. The authors are grateful to Professor Claude Payri and Lydie Mao Che (University of French Polynesia) and Tea Frogier (Ministry of Research of French Polynesia) for help and providing facilities for sampling and experimental work on site. Françoise Reiss and Chantal Astier are acknowledged for their analysis and determination of carotenoid pigments.

\section{References}

Buffan-Dubau, E., De Wit, R. \& Castel, J. (1996). Feeding selectivity of the harpacticoid copepod Canuella perplexa in benthic muddy environments demonstrated by HPLC analyses of chlorin and carotenoid pigments. Mar Ecol Prog Ser 137, 71-82.

De Ley, J., Cattoir, H. \& Reynaerts, A. (1970). The quantitative measurement of DNA hybridization from renaturation rates. Eur J Biochem 12, 133-142.

Felsenstein, J. (1993). PHYLIP (phylogeny inference package), version 3.5c. Distributed by the author. Department of Genome Sciences, University of Washington, Seattle, USA.

Garcia, D., Parot, P., Vermeglio, A. \& Madigan, M. T. (1986). The light-harvesting complexes of a thermophilic purple sulfur photosynthetic bacterium Chromatium tepidum. Biochim Biophys Acta 850, 390-395.

Glaeser, J. \& Overmann, J. (1999). Selective enrichment and characterization of Roseospirillum parvum, gen. nov. and sp. nov., a new purple nonsulfur bacterium with unusual light adsorption properties. Arch Microbiol 171, 405-416.

Guyoneaud, R., Moune, S., Eatok, C., Bothorel, V., Hirschler-Rea, A., Willison, J., Duran, R., Liesack, W., Herbert, R. \& other authors (2002). Characterization of three spiral-shaped purple nonsulfur bacteria isolated from coastal lagoon sediments, saline springs, and microbial mats: emended description of the genus Roseospira and description of Roseospira marina sp. nov; Roseospira navarrensis sp. nov., and Roseospira thiosulfatophila sp. nov. Arch Microbiol 178, 315-324.

Hiraishi, A., Urata, K. \& Satoh, T. (1995). A new genus of marine budding phototrophic bacteria, Rhodobium gen. nov., which includes Rhodobium orientis sp. nov. and Rhodobium marinum comb. nov. Int J Syst Bacteriol 45, 226-234.
Huß, V. A. R., Festl, H. \& Schleifer, K. H. (1983). Studies on the spectrometric determination of DNA hybridization from renaturation rates. Syst Appl Microbiol 4, 184-192.

Imhoff, J. F. (1983). Rhodopseudomonas marina sp. nov., a new marine phototrophic purple bacterium. Syst Appl Microbiol 4, 512-521.

Lane, D. J. (1991). 16S/23S rRNA sequencing. In Nucleic Acid Techniques in Bacterial Systematics, pp. 115-175. Edited by E. Stackebrandt \& M. Goodfellow. Chichester: Wiley.

Mao Che, L., Andréfouët, S., Bothorel, V., Guezennec, M., Rougeaux, H., Guezennec, J., Deslandes, E., Trichet, J., Matheron, R. \& other authors (2001). Physical, chemical, and microbiological characteristics of microbial mats (KOPARA) in the South Pacific atolls of French Polynesia. Can J Microbiol 47, 994-1012.

Mesbah, M., Premachandran, U. \& Whitman, W. B. (1989). Precise measurement of the $\mathrm{G}+\mathrm{C}$ content of deoxyribonucleic acid by highperformance liquid chromatography. Int J Syst Bacteriol 39, 159-167.

Overmann, J., Fischer, U. \& Pfennig, N. (1992). A new purple sulfur bacterium from saline littoral sediments, Thiorhodovibrio winogradskyi gen. nov. and sp. nov. Arch Microbiol 157, 329-335.

Pfennig, N. \& Trüper, H. G. (1992). The family Chromatiaceae. In The Prokaryotes, 2nd edn, pp. 3200-3221. Edited by A. Balows, H. G. Trüper, M. Dworkin, W. Harder \& K. H. Schleifer. New York: Springer.

Pfennig, N. \& Wagener, S. (1986). An improved method of preparing wet mounts for photomicrographs of microoganisms. J Microbiol Methods 4, 303-306.

Pfennig, N., Widdel, F. \& Trüper, H. G. (1981). The dissimilatory sulfate-reducing bacteria. In The Prokaryotes, vol. 1, pp. 926-940. Edited by M. P. Starr, H. Stolp, H. G. Trüper, A. Balows \& H. G. Schlegel. Berlin: Springer.

Pfennig, N., Lünsdorf, H., Süling, J. \& Imhoff, J. F. (1997). Rhodospira trueperi gen. nov., sp. nov., a new phototrophic proteobacterium of the alpha group. Arch Microbiol 168, 39-45.

Precigou, S., Goulas, P. \& Duran, R. (2001). Rapid and specific identification of nitrile hydratase (NHase) encoding genes in soil samples by polymerase chain reaction. FEMS Microbiol Lett 204, 155-161.

Reynolds, E. S. (1963). The use of lead citrate at high $\mathrm{pH}$ as an electron opaque stain in electron microscopy. J Cell Biol 17, 208-212.

Weisburg, W. G., Barns, S. M., Pelletier, D. A. \& Lane, D. J. (1991). 16 S ribosomal DNA amplification for phylogenetic study. J Bacteriol 173, 697-703. 